\title{
THE CRITICAL SOIL WATER CONTENT AND ITS RELATION TO SOIL WATER DYNAMICS
}

\author{
Q. de JONG VAN LTRR ${ }^{1,2}$ \\ ${ }^{1}$ Depto. de Solos-FANFRCS, C. P. 776, CEP: 90001-970 - Porto Alezre, RS, Bradh \\ ${ }^{1}$ Bolnista do CNPq.
}

\begin{abstract}
Uing in elaphle model that deseribes the extraction of woll water by plant roots, the ocenrrence of depletion zones close to plant roots is demonetrated. These depletion zones affect the root water potential that is meeded to maintain a certinin tranopiration rate. The results show how the eritical soll water content depends on soll's Inydrunlic properties, trunopiration rate and root density.

Key Words: Critical soll water content, soll water extraction, soll water dynamics
\end{abstract}

\section{A UMIDADE CRTITCA E SUA RELAÇÃo COM A DINÂMTCA DA ÁGA NO SOLO}

\begin{abstract}
RESUMO: Atraves de un modelo edifico que desereve a extraghio de figut do solo por rafres, e comprovada a

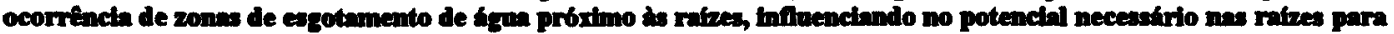

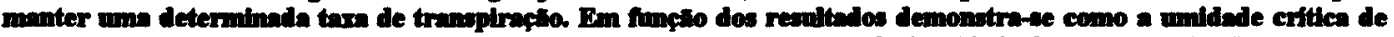
um solo e fungilo de man propriedades hidricas, da taxa de trangifraclio e da densidade do sistema radicular.

Descrttores: umidade crítica, extrapito da f́gua do solo, dinimica da figa no solo
\end{abstract}

\section{INTRODUCTION}

The need of intake of carbon dioxide through stomata, the water-vapor saturated conditions inside of these and the usual lower relative humidity of the surrounding air make that plants loose water by transpiration. Supply of soil water to plant roots should compensate for this loss. Water potentials in root and shoot are adjusted to meet uptake requirements. As the soil water content reduces, matric potentials and hydraulic conductivities diminish, making necessary increasing differences of water potential between soil and root in order to maintain a satisfactory water flux. Water potentials within plant roots may decrease down to $-500 \mathrm{kPa}$ (Adeoye \& Rawlins, 1981), but at some moment before this, the soil-root water flux becomes insufficient and the plant closes its stomata. The soil water content at the moment of the first reduction in stomata opening is called the critical soil water content. Doorenbos et al. (1980) described the critical soil water content as a function of plant sensibility to drought and evapotranspiration demand, not taking into account the soil's hydraulic properties. However, many authors confirmed that the movement of water from soil to root surface is the most limiting step in the overall process of water flux from soil to atmosphere (Gardner \& Ehlig, 1962; Macklon \& Weatherley, 1965; Carbon, 1973; Zur et al., 1982; Hulugalle \& Willatt, 1983; Hainsworth \& Aylmore, 1986, 1989; Tardieu et al., 1992). This paper aims to show the importance of the hydraulic properties of the depletion zone on determining the critical soil moisture content. The influence of root density and soil hydraulic properties are elucidated, applying a physical model that describes soil water extraction by plant roots.

\section{MATERIAL AND METHODS}

The value of the matric potential at any place within the depletion zone of a single root can be related to parameters of the plant, the atmosphere and the soil, by the following equation (Jong van Lier, 1994):

$$
\psi_{x}=\psi_{s}+\frac{T \cdot A}{2 . \pi \cdot l} \int_{R_{1}}^{x} \frac{1}{K_{x} \cdot(r+x)} d x
$$

where $T\left(\mathrm{~m}^{3} \cdot \mathrm{m}^{-2} \cdot \mathrm{s}^{-1}\right)$ is the transpiration rate, $A\left(m^{2}\right)$ is the ground area occupied by the plant, $I(m)$ is the total root length, $r(m)$ is the uniform root radius, $x(m)$ is the distance from the root, $y_{z}$ 
is the matric potential outside the depletion zone and $R_{t}(m)$ is the distance the drying front advanced at time $t$. This model was used to perform simulations for an entire hypothetical root system of a plant with a ground area of $0.01 \mathrm{~m}^{2}$, extending to a depth $\mathrm{z}$ of $0.3 \mathrm{~m}$, having mean and regular distances $(\mathrm{d}, \mathrm{m})$ between roots. It can be deduced that, in this case, the total root length 1 equals

$$
l=\frac{4 \cdot A \cdot z}{\pi \cdot d^{2}}
$$

We simulated for transpiration rates of 5 and 10 mm.day ${ }^{-1}$ and for distances between roots of $0.1,0.05,0.03,0.01$ and $0.001 \mathrm{~m}$, considering the initial soil water content to be equal to the soil water content at matric potential $-10 \mathrm{kPa}$.

As the analytical solution of equation 1 is not possible, because of the dependence of $K_{x}$ on $y_{x}$, a software was developed to perform a discrete integration with distance increments $(\mathrm{dx})$ of $10^{-5} \mathrm{~m}$. Water potential distribution in the depletion zone was calculated for any root water potential between -10 and $-1000 \mathrm{kPa}$ (entire numbers only) by the equation

$$
\psi_{x}=\psi_{x-1}+\frac{10^{-5} \cdot T \cdot A}{2 \cdot \pi \cdot l \cdot K_{x}(r+x)}
$$

where $y_{x-1}$ is the matric potential in the circumference one increment closer to the root than $y_{x}$. The first value of $y_{x-1}$ was taken equal to $y_{\text {root. }}$. The simulation was stopped when $y_{x}$ equaled $y_{s}$. Then, $x$ was considered to be equal to $R_{r}$. The time needed to reach the correspondent root potential was calculated by

$$
t=\frac{2 \cdot \pi \cdot l}{T \cdot A} \int_{r}^{R_{t}} x \cdot\left(\theta_{s}-\theta_{x}\right) \cdot d r
$$

where $q_{x}$ and $q_{s}$ were calculated by the Van Genuchten (1980) equation, based on $y_{x}$ and $y_{s}$.

Data of water retention and hydraulic conductivity of the surface horizon of two distinct soils from the township of Piracicaba, Brazil, were used for the simulations: a medium textured red-yellow oxisol (RY), and a very clayey red oxisol (RD). The relation $y(q)$ was described by the Van Genuchten (1980) equation, while K(q) was calculated using the equation proposed by Reichardt \& Libardi (1974):

$$
K(\theta)=8.770 .10^{-4} \cdot \frac{d \psi_{m}}{d \theta} \cdot f^{2} \cdot e^{8087^{\theta-\theta_{6} / \theta_{1}-\theta_{0}}}
$$

The empirical parameters of these equations, determined by Jong van Lier (1994) for these two soils, are shown in TABLE 1.

TABLE 1 - Empirical parameters of the Van Genuchten (1980) and Reichardt \& Libardi (1974) equations for the two soils used in the simulations.

\begin{tabular}{cccc}
\hline parameter & equation & \multicolumn{2}{c}{ soil } \\
\cline { 3 - 4 } & Van Genuchten $(1980)$ & 0.004 & $\mathrm{RD}$ \\
\hline $\mathrm{q}_{\mathrm{r}}\left(\mathrm{m}^{3} \cdot \mathrm{m}^{-3}\right)$ & Van Genuchten $(1980)$ & 0.390 & 0.115 \\
$\mathrm{q}_{\mathrm{s}}\left(\mathrm{m}^{3} \cdot \mathrm{m}^{-3}\right)$ & Van Genuchten (1980) & 0.3170 & 0.509 \\
$\mathrm{a}\left(\mathrm{kPa}^{-1}\right)$ & Van Genuchten $(1980)$ & 0.2148 & 0.4302 \\
$\mathrm{~m}$ & Van Genuchten $(1980)$ & 3.4779 & 0.1632 \\
$\mathrm{n}$ & Reichardt \& Libardi $(1974)$ & 0.004884 & 2.8748 \\
$\mathrm{f}\left(\mathrm{m}^{-1} \mathrm{~s}^{-1}\right)$ & Reichardt \& Libardi (1974) & 0.3602 & 0.000698 \\
$\mathrm{q}_{1}\left(\mathrm{~m}^{3} \cdot \mathrm{m}^{-3}\right)$ & Reichardt \& Libardi (1974) & 0.0153 & 0.4863 \\
$\mathrm{q}_{0}\left(\mathrm{~m}^{3} \cdot \mathrm{m}^{-3}\right)$ & & & 0.0308 \\
\hline
\end{tabular}




\section{RESULTS AND DISCUSSION}

Simulation results show that differences between rooting densities decrease when rooting density increases (Figures 1 and 2). These figures also show that differences between mean distances of 0.01 and $0.001 \mathrm{~m}$ appeared to be very small for both soils and transpiration rates, indicating that, as far as water extraction concerns, there is little advantage for a plant to have smaller distances between adjacent roots than $0.01 \mathrm{~m}$. Comparing between the two soils, soil RY, with a higher hydraulic conductivity, allows plants to extract soil water with less negative root water potentials for a longer time.

(a)

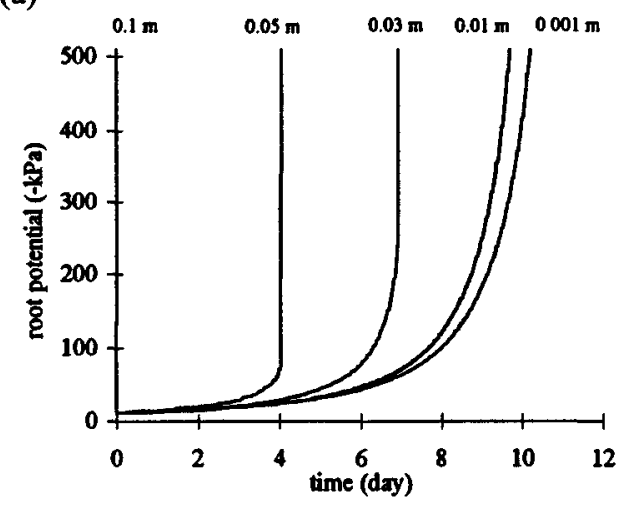

(b)

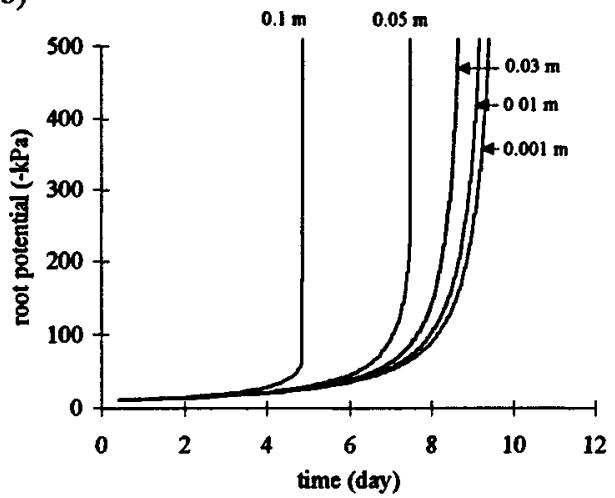

Figure 1 - Root potential needed to maintain a water flux equivalent to the transpiration rate of $5 \mathrm{~mm}^{-d a y}{ }^{-1}$, for the soils RD (a) and RY (b) and for different distances between roots.
To illustrate the efficiency of soil water extraction in different situations, TABLE 2 shows the mean matric potential within both soils at both transpiration rates and for different distances between roots, when the root water potential attains $-500 \mathrm{kPa}$. In the case of total efficiency, this potential should be $-500 \mathrm{kPa}$, as occurs in all situations with distance between roots of $0.001 \mathrm{~m}$. In the case of no efficiency at all, the potential should be $-10 \mathrm{kPa}$, the initial soil water potential. Values very close to $-10 \mathrm{kPa}$ are obtained with a root distance of $0.1 \mathrm{~m}$, especially in soil RD. This tendency can be confirmed in Figures 1 and 2, where the $0.1 \mathrm{~m}$-curves for soil RD rapidly show very negative root potentials.

(a)

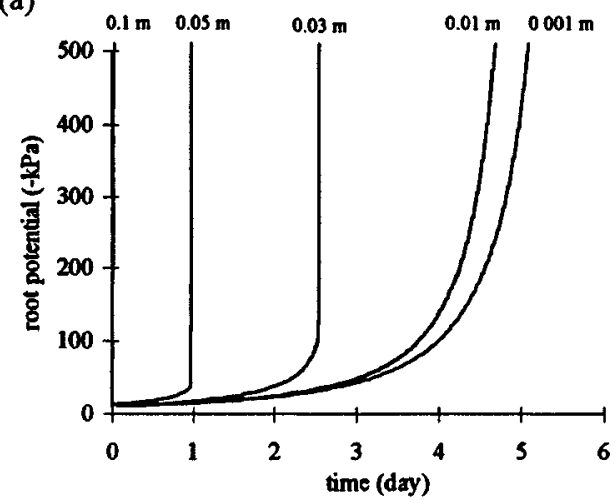

(b)

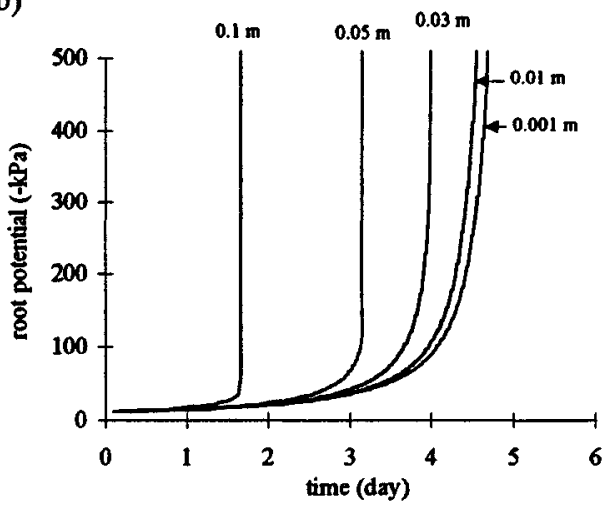

Figure 2 - Root potential needed to maintain a water flux equivalent to the transpiration rate of $10 \mathrm{~mm}$.day ${ }^{-1}$, for the soils RD (a) and RY (b) and for different distances between roots. 
TABLE 2 - Mean matric potential (kPa) within soils RD and RY at two different transpiration rates and for different distances between roots, when the root water potential attains $-500 \mathrm{kPa}$.

\begin{tabular}{ccccc}
\hline $\begin{array}{c}\text { Distance between roots } \\
(\mathrm{m})\end{array}$ & $\begin{array}{c}\mathrm{RD} \\
5 \mathrm{~mm} \cdot \mathrm{day}{ }^{-1}\end{array}$ & $\begin{array}{c}\mathrm{RY} \\
5 \mathrm{~mm} . \text { day }\end{array}$ & $\begin{array}{c}\text { RD } \\
\text { 10 mm.day }\end{array}$ & $\begin{array}{c}\text { RY } \\
10 \text { mm.day }\end{array}$ \\
\hline 0.001 & -500 & -500 & -500 & -500 \\
0.01 & -364 & -455 & -274 & -401 \\
0.03 & -65 & -188 & -33 & -101 \\
0.05 & -24 & -72 & -15 & -41 \\
0.1 & -11 & -25 & -11 & -18 \\
\hline
\end{tabular}

On varying distances between roots from 0.01 to $0.05 \mathrm{~m}$, at a transpiration rate of $5 \mathrm{~mm}^{-d a y^{-1}}$, the mean matric potential in soil RY passes from $-72 \mathrm{kPa}$ to $-455 \mathrm{kPa}$ (TABLE 2). This tendency can be confirmed in Figure 3 which shows the matric potential in the depletion zone of soil RY as a function of distance from root surface, when the root surface potential attains $500 \mathrm{kPa}$ at a transpiration rate of $5 \mathrm{~mm}$. day ${ }^{-1}$, for distances between roots of 0.01 and $0.05 \mathrm{~m}$. This indicates that different critical soil moisture contents have to be taken into account when plants with different root densities are considered, or when roots are not equally distributed within the soil, which often happens due to the tendency of roots to follow pre-existing channels (Tardieu \& Manichon, 1986; Wang et al., 1986).
At a root distance of $0.01 \mathrm{~m}$ and a transpiration rate of $5 \mathrm{~mm}^{-d a y}{ }^{-1}$, the mean matric potential is $-364 \mathrm{kPa}$ in soil $\mathrm{RD}$ and $-455 \mathrm{kPa}$ in soil RY at the moment that the root surface potential attains $-500 \mathrm{kPa}$. Figure 4 illustrates this situation. In TABLE 2 it can be seen that the differences between the two soils increase when transpiration rates increase. This shows that transpiration rates have to be considered when estimating the critical soil moisture content. However, they cannot be seen apart from soil hydraulic conductivity. In Figure 5, the influence of transpiration rates is illustrated once more. At high transpiration rates, potential gradients must be higher, resulting in a less efficient extraction of water between plant roots. Mean matric potential for soil RY with a root distance of $0.01 \mathrm{~m}$ is $-455 \mathrm{kPa}$ at a transpiration rate of $5 \mathrm{~mm}$.day ${ }^{-1}$, and $-401 \mathrm{kPa}$ at a rate of $10 \mathrm{~mm}$.day- ${ }^{-1}$.

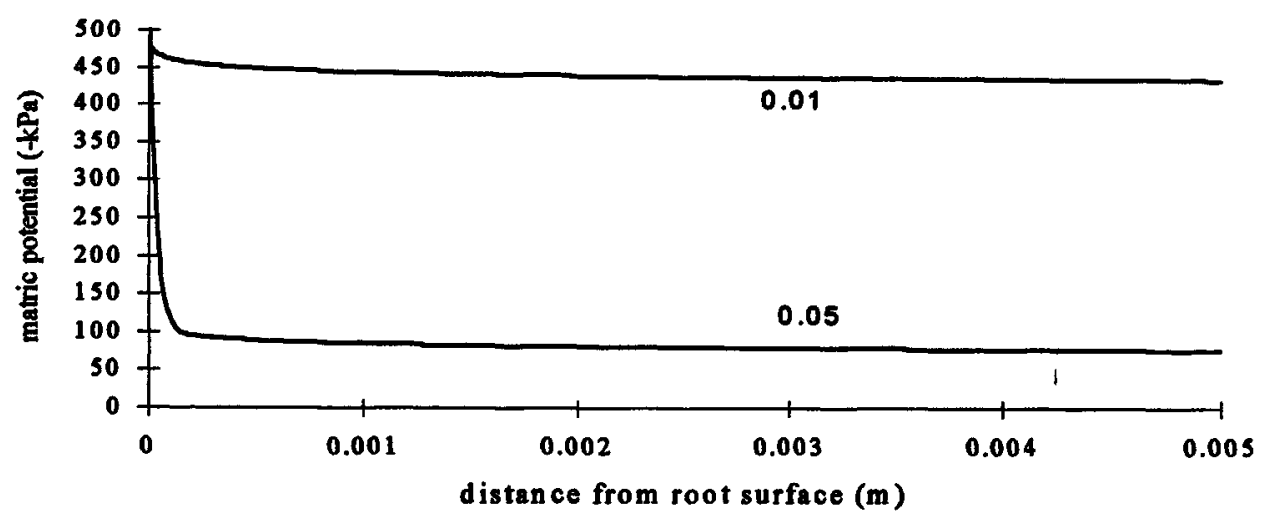

Figure 3 - Matric potential in the depletion zone of soil RY as a function of distance from root surface, when root surface potential attains $-500 \mathrm{kPa}$ at transpiration rate of $5 \mathrm{~mm}^{-d a y^{-1}}$, for distances between roots of 0.01 and $0.05 \mathrm{~m}$. 


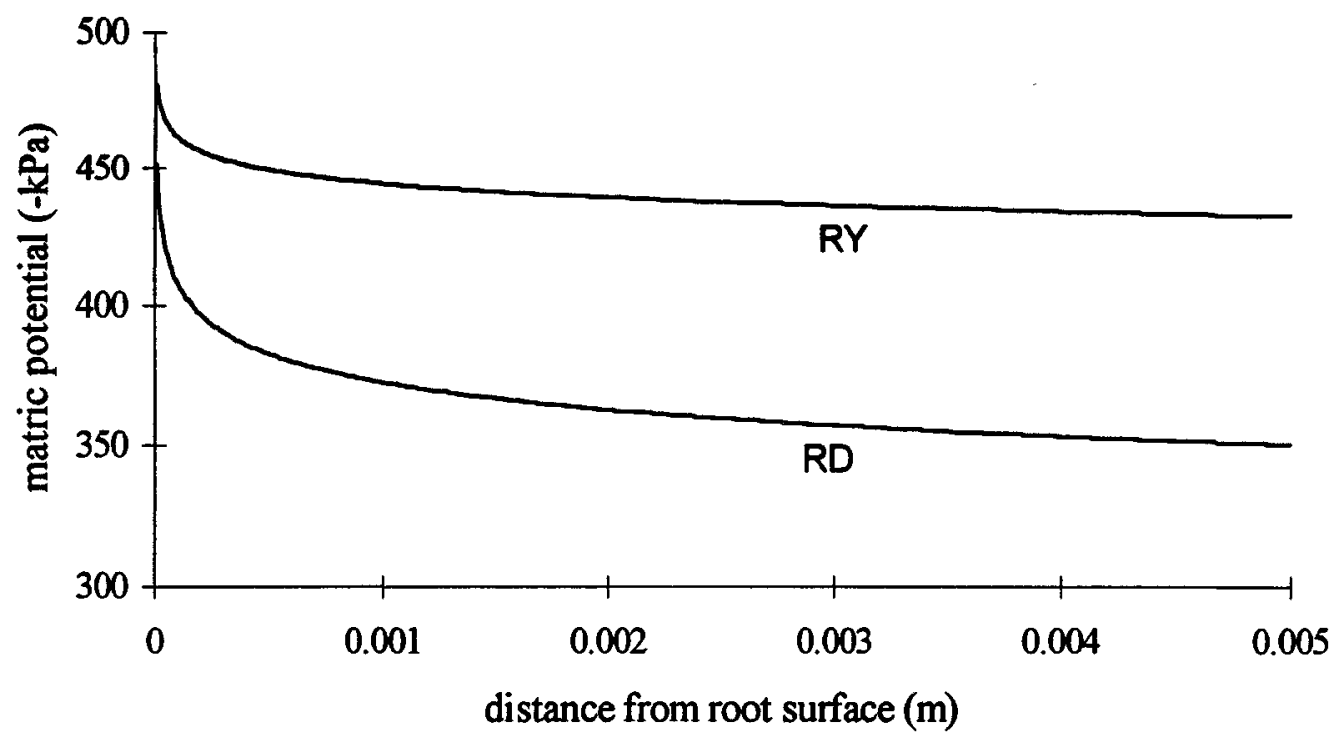

Figure 4 - Matric potential in the depletion zones of soils RD and RY as a function of distance from root surface, when root surface potential attains $-500 \mathrm{kPa}$ at transpiration rate of $5 \mathrm{~mm}$.day ${ }^{-1}$ (distance between roots: $0.01 \mathrm{~m}$ )

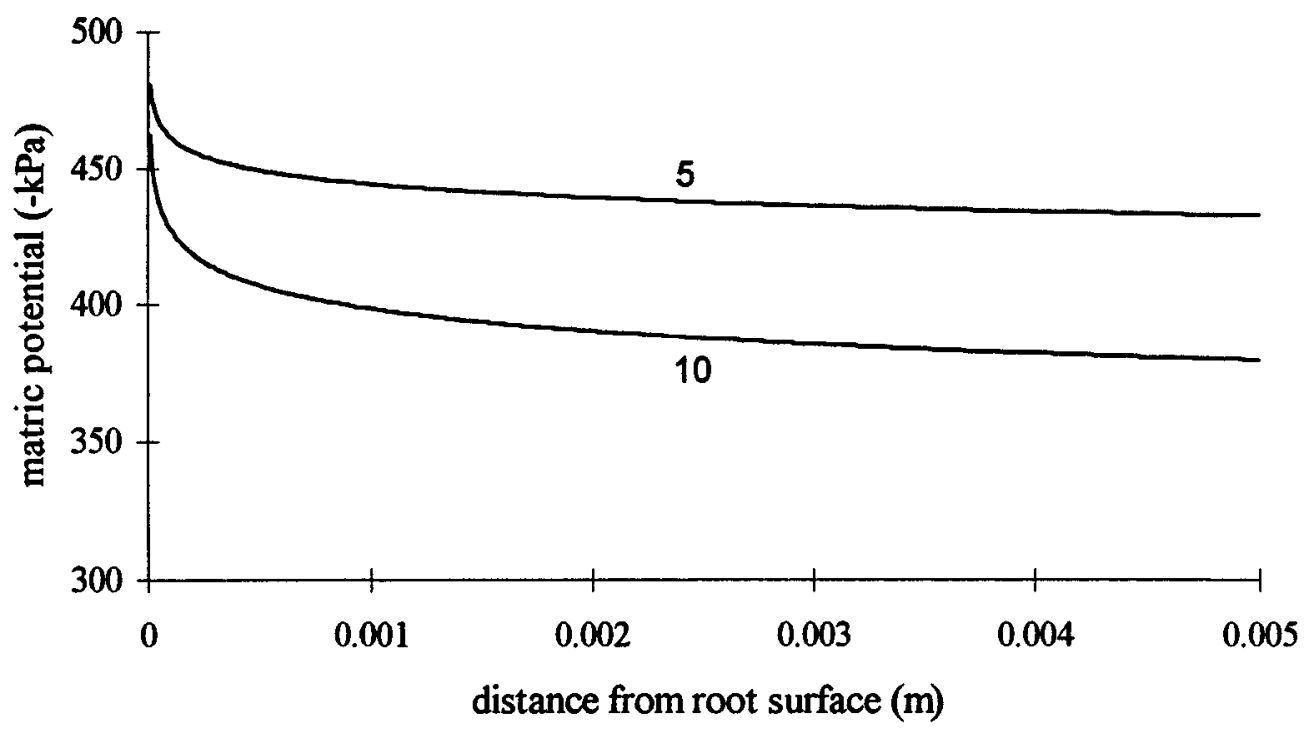

Figure 5 - Matric potential in the depletion zone of soil RY as a function of distance from root surface, when root surface potential attains $-500 \mathrm{kPa}$ at transpiration rates of 5 and $10 \mathrm{~mm}$.day- ${ }^{-1}$ (distance between roots: $0.01 \mathrm{~m}$ ). 


\section{CONCLUSTONS}

Simulation results allow to conclude that depletion zones do occur close to root surfaces, when the distance between neighboring roots exceeds $0.001 \mathrm{~m}$. Therefore, on determining the critical soil water content the soil's hydraulic properties should be taken into account, as well as the transpiration rate and the root density. The proposed model allows to do so, and can be used to evaluate the way in which the involved parameters interfere.

\section{REFERENCES}

ADEOYE, K.B.; RAWLINS, S.L. A split-root technique for measuring root water potential. Plant Physiology, v.68,p.44-47, 1981

CARBON, B.A. Diumal water stress in plants grown on a course soil. Autrallian Jommal of Soll Research, v.11: $33-42,1973$

DOORENBOS, J.; KASSAN, A.H.; BENTVELSEN, C.L.M.; BRANSCHEID, V.; PLUSJE, J.M.G.A.; SMITH, M.; UITTENBOGAARD, G.O.; VAN DER WAL, H.K. Yield response to water. Rome, FAO, 1979, 193p. (Irrigation and Drainage paper 33).

GARDNER, W.R; EHLIG, C.F. Some observations on the movement of water to plant roots. Agronomy Journal, v.54,p.453-456, 1962.

HANSWORTH, J.M.; AYLMORE, LA.G. Water extraction by single plant roots. Soll Seience Society of America Jourmal, v.50,p.841-848, 1986.

HAINSWORTH, J.M.; AYLMORE, L.A.G. Nonuniform soil water extraction by plant roots. Plant and Soll, v.113, p.121-124, 1989.

HULUGALLE, N.R.; WILLATT, S.T. The role of soil resistance in determining water uptake by plant root systems. Amstralian Jourmal of Soll Research, v.21,p.571-574, 1983.
JONG VAN LIER, $Q$. de Extraçio da água do solo por plantas: desenvolvimento e validacio de um modelo. Piracicaba, 1994. 96p. (Tese) Doutorado - Escola Superior de Agricultura "Luiz de Queiroz", Universidade de Sto Paulo.

MACKLON, A.E.S.; WEATHERLEY, P.E. Controlled enviromment studies of the nature and origins of water deficits in plants. New Phytologist, v.64, p.414-427, 1965.

REICHARDT, K.; LIBARDI, P.L. A new equation to estimate soil-water diffusivity. Isotope and Radiation Techniques in Soil Physics and Irrigation Studies 1973, Viena, (International Atomic Energy Agency), p.45-51, 1974

TARDIEU, F.; BRUCKLER, L.; LAFOLIE, F. Root clumping may affect the root water potential and the resistance to soil-root water transport. Plant and Soll, v.140, p.291-301, 1992.

TARDIEU, F.; MANICHON, H. Caractérisation en tant que capteur d'eau de l'enracinement du mais en parcelle cultivée. 2. Une methode d'tude de la répartition verticale et horizontale des racines. Agronomie, v.6, p.415-425, 1986.

VAN GENUCHTEN, M.Th. A closed-form equation for predicting the bydraulic conductivity of unsaturated soils. Soll Sclence Soclety of America Journal, v.44, p.892-897, 1980.

WANG, J.; HESKETH, J.D.; WOOLLEY, J.T. Preexisting channels and soy-bean rooting patterns. Soll Sclence, v.141, p.432-437, 1986.

ZUR, B.; JONES, J.W.; BOOTE, K.J.; HAMMOND, L.C. Total resistance to water flow in field soybeans: II. Limiting soil moisture. Agronomy Journal, v.74, p.99-105, 1982.

Recebido para publicagăo em 02.05 .97

Aceito para publicaçio em 10.05.97 